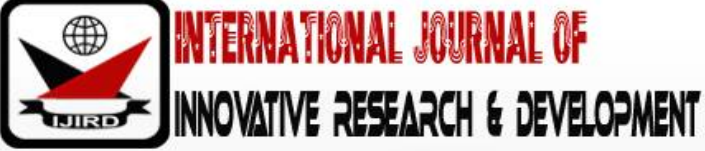

ISSN 2278 - 0211 (Online)

\section{School-based Health Service Delivery in Ghana: The Actualities of an Observation}

\author{
Dr. Eric Mensah \\ Lecturer, Department of Arts Education, College of Education Studies, \\ University of Cape Coast, Ghana
}

\begin{abstract}
:
There is no argument over the importance of students' health in relation to the attainment of set goals for education. To this end, the study aimed at assessing the state of school-based health service delivery in public senior high/ technical schools in Ghana. Focus was on the public senior high/technical schools in the Eastern, Western and Central regions of Ghana. All the 210 public senior high/ technical school in the three regions were selected for thestudy. The descriptive cross-sectional census survey was adopted for the study. Data was collected with a structured observation guide ( 0.78 , Cronbach Alpha coefficient) that consisted of three sections and 20 items that looked at the availability and non-availability of indicators of school-based health services delivery. Data collected was analysed with Microsoft Excel (v.2018). Results from the data analysis signposted, among others, that almost half $(\mathrm{n}=103$,

49\%) of the 210 public senior high/ technical schools in the Eastern, Western and Central regions of Ghana do not have school-based health delivery facility (Sickbay). Also, only 63 (30\%) of the 210 schools had a health professional, with only 33 $(16 \%)$ of these schools having a Medical Doctor visiting once every two weeks. It was recommended, among others, that Government revisits the rationale behind School Health Education Programme

(SHEP) to revive the need for health promotion and delivery and also reignite the supposed collaboration betweenthe Ministry of Education and the Ministry of Health towards that direction.
\end{abstract}

Keywords: School health, school-based health service delivery, students

\section{Introduction}

The school is an institution charged with the mandate of providing programmes, courses and subjects for students to learn and gain experiences for life. These programmes and courses focus on the cognitive or mental development of the learner (student). Students spend a considerable amount of time in the school, which exposes them to various environmental, social, emotional and physical influences. Schools have the most direct influence on a child's health, apart from the child health systems (Ran, Chattopadhyay, \& Hahn, 2016). This means that the school's role goes beyond the provision of education, to include social, emotional as well as health issues (Ofovwe \& Ofilli, 2007). It is an obvious fact that for students to function properly and gain from the school, they have to be physically, mentally and emotionally healthy. Acosta Price (2016) puts this in proper context when he opined that, in order for learners to get the greatest opportunity of becoming useful and well, child-serving structures need to synchronize their care and services. He identified two important sectors, education and health as playing crucial roles in encouraging improved results for child well-being and long-term success. Therefore, the school should collaborate with the health systems to be able to provide some health delivery in order for students to be able to deal with some of the exposures such as injuries, emotional problems and infections (Weinstein, 2006). School-based health centres (SBHCs)/ Sickbays are avenues through which schools and the health care system can cooperate very efficiently to tackle the difficult health needs of learners (Acosta Price, 2016).

The need for school-based health service delivery cannot be overemphasised. While a commonly established definition of the term 'school health services' has not been assumed, Small, Majer, Allens worth, Farquhar, Kann, and Pateman (1995)described school health services as a coordinated system that ensures a continuum of care from school to home to community health care provider and back. It has been given different names in different countries and jurisdictions. But generally, they all talk about providing good health delivery systems for the students. School-based health service delivery has history. According to Gustafson (2005) and Vessey and McGowan (2006), school-based health began in the early 1900s by the public health nursing movement due to high rate of absenteeism in schools. These absenteeism rates were caused by the spread of communicable diseases such as measles, scarlet fever, whooping cough and tuberculosis. Children were sent home because the school could not treat them, an action that saw more children being infected. Vessey and McGowan (2006) revealed that, the first school nurse was Lina Rogers who in 1902 was brought in to help. Within a year, the rates of absenteeism in schools reduces by almost $90 \%$ and they arose the need for school nurses in the United States of America. 
School-based health delivery is to provide physical and mental health services on school campuses to improve student health status, and thereby potentially facilitate student academic success. Apart from treating students, over the years the role of the school nurse who is a component of school-based health delivery has expanded from health education to include aspects of primary health care, immunizations, health screening and referrals (Gustafson, 2005).Proctor, Lordi, and Zarger (1993) outline the following as the services that school-based health and the school nurse should provide

- Physical and mental health assessment and referral for care;

- Development and implementation of health care plans for students with special health care needs;

- Health counselling;

- Mandated screenings, such as vision, hearing, and immunization status;

- Monitoring the presence of infectious conditions among students and enforcing public health precautions to prevent spread of infections and infestations;

- Skilled nursing services for students with complex health care needs;

- Case management of students with chronic and special health care needs;

- Outreach to students and their families;

- Interpretation of the health care needs of students to school personnel;

- Development and implementation of emergency care plans and provision of emergency care and first aid;

- Serving as liaison for the school, parents, and community health agencies; and

- Collaboration with other school professionals-particularly counsellors, psychologists, and social workers-to address the health, developmental, and educational needs of students.

Recently, Ofovwe and Ofilli (2007) also said, a school health programme should include the following eight components: parent/community involvement;healthful school environment; health services; health education; physical education; nutrition services; counselling, psychological, and social services; and health promotion for school staff. In addition to these roles or services, Keeton, Soleimanpour and Brindis (2012) also indicated that school health programmes should serve as a link with medical homes, serve the adolescent and the minority underserved population in the school. They added health issues like, reproductive health, obesity, oral health alcohol and substance abuse, caring for children with special needs etc. as some of the issues.

The importance attached to the health of students has given school-based health delivery the needed attention and focus over the years. Countries all over the world have come to accept that for learning to take place, learners must be healthy. Due to this, developed countries have made it compulsory and a must for schools to have a health delivery system. A look at the websites of schools in developed countries indicates the seriousness with which they handle issues of health care delivery. This according toOlugbenga, Olorunfemi and Opeyemi (2016), is because globally the number of children reaching school age is estimated to be 1.2 billion children (18\% of the world's population) and rising. In many homes across the world, children start to attend school from as early as 5-6 months because mothers have to wean early to return to their work place. This means that parents do not spend much time with their kids and therefore may not be able to monitor their health to detect issues. The purpose of the school health services, therefore, is to help children at school to achieve the maximum health possible for them to obtain full benefit from their education. Also, in developing countries efforts are being made to provide school-based health service because literacy rate is low and childhood mortality is high and for success to be attained in education there is the need for good and properly organized school-based health delivery (Ofovwe \& Ofilli, 2007). Aside these, it has also been established that, there is a relationship between school-based health delivery and academic performance. Geierstanger, Amaral, Mansour and Walters (2004) established that SBHC has a positive influence on academic performance and that healthy children make better students. However, many studies that focused on factors affecting academic performance neglected the variable SBHC.

Schools at the various levels have facilities named differently that provide health services. From School-based health centres to Sickbays, these facilities provide on-spot health services for students and staff of these educational institutions (Acosta Price, 2016). The importance attached to the health of students when it comes to education, has led to the conduct of many studies( Ofovwe \& Ofilli, 2007; Strolin-Goltzman, 2010; Basch, 2011; Toma, Oyebode, Toma, \& Agaba, 2014; Olugbenga, Olorunfemi, \& Opeyemi, 2016; Bains, \& Diallo, 2016), to find out the state of health delivery in schools globally.Strolin-Goltzman (2010) for instance found from his study that, schools with school-based health centres/ sickbays were seen as favourable by both students and parents in the promoting of education as compared to those without. These schools provided students with quality health- care and were associated with greater satisfaction in 3 out of 4 learning environment domains.The study however failed to indicate the conditions of the health centres in the schools.Toma, Oyebode, Toma, and Agaba (2014) revealed that health delivery systems in public schools in Nigeria are poor as compared to private schools. Only $36.4 \%$ of schools they looked at had health personnel. There were no health centres or sickbays in almost all the public schools whiles $75.8 \%$ of the schools administered first aid to injured / ill children through teachers.Similarly, Olugbenga, Olorunfemi and Opeyemi (2016) and Ofovwe and Ofilli (2007) all found from their study that, there were no health centres/ Sickbays and health personnel or a trained first aider in most public schools. Again, some schools had no toilet facility, 33.3\% had pit latrine while $40.0 \%$ had water closet.

\section{Context and Purpose of Study}

The health of students plays a vital role in the attainment of education objectives. In order for society to attain maximum benefit for education, the school needs to collaborative with health systems in order to provide good health services for students (Weinstein, 2006; Acosta Price, 2016). Due to this, educational systems all over the world have put in measures and programmes to ensure that schools are well equipped to provide some health services to their students. 
In Ghana, the School Health Education Programme (SHEP) unit under the Ghana Education Service is tasked with the responsibility for Health Promotion in schools up-to Pre-tertiary level. It was established in 1992 as follow-up actions on Ghana's commitment to the Jomtien World Declaration on Education for All and her ratification of the United Nations Convention of the Rights for the Child. It was established as a joint mandate to the Ministry of Education (MoE) and the Ministry of Health (MoH). The mission of the two ministries was to facilitate the provision of health education to the door steps of school children for early detection of disability and also to inculcate into them health promotion habits, attitudes and values as means of improving child survival, school attendance, retention and achievements. The programme sought to:

- Conduct training to build capacity of teachers, school children and community members for the effective implementation of school health programmes;

- Develop appropriate Information, Education and Communication (IEC) materials;

- Inculcate into school children health-promoting habits and values of good hygiene and sanitation practices including hand washing with soap;

- Bring health education and related health services to the doorsteps of school children for early detection of defects and disability for prompt referral and management;

- Assist in the prevention and management of communicable and non-communicable diseases;

- Promote good environmental sanitation and hygiene practices in schools, which are gender friendly;

- Promote healthy lifestyles including healthy diet, avoiding alcohol and tobacco consumption, illicit drugs, physical inactivity and premarital sex.

Despite putting in place these elaborate objectives, structures for programme, mission, vision and collaborating institutions, SHEP has failed to live up to expectation and also failed to institute mandatorily a school-based health centres/ sickbay which are avenues through which schools and the health care system can cooperate very efficiently to tackle the difficult health needs of students (Acosta Price, 2016).Boateng (2008) looked at the implementation and practice of school health programme is some basic schools in the Kwabre district of the Ashanti Region in Ghana. She found weak collaboration between implementers, inadequate funding, and inadequate support from the health sector among others as challenges of the programme.

A personal experience in a Senior high school in the Eastern region of Ghana revealed the availability of a school health centre but absence of a health professional. The sick student had to be rushed to a nearby hospital for treatment. There have also been outbreak of various diseases and infections in many senior high schools. In December 2017, Kumasi Academy Senior High School in the Ashanti region of Ghana recorded an outbreak of a disease which killed about four students. Preliminary investigations showed that the school did not have a proper school-based health system in place, not to talk about a health centre/ sickbay.

Several studies (Ofovwe \& Ofilli, 2007; Strolin-Goltzman, 2010; Keeton, Soleimanpour \& Brindis, 2012; Basch, 2011; Toma, Oyebode, Toma, \& Agaba, 2014; Olugbenga, Olorunfemi, \& Opeyemi, 2016; Bains, \& Diallo, 2016;Ran, Chattopadhyay, \& Hahn, 2016) have been conducted elsewhere to assess school-based health services/ centres. In the Ghanaian context, Nyonator, Awoonor-Williams, Phillips, Jones, and Miller (2005) and Tierozie (2011) conducted studies on community-based health planning and service deliveries. Their concentration was not on health delivery in schools. Boateng (2008) concentrated on the implementation and practice of school-based health programme is some basic schools.However, none of these studies focused on senior high schools in Ghana. One wonders what the situation is in the various senior high schools with regards to school-based health delivery. Questions that come to mind include; are there school-based health administrative structures in the school? Are there school-based health centres? What are the conditions of these health centres? The need to find answers to these pertinent issues and also fill the gap in the literature necessitated the assessment of School-Based Health Service delivery in Public Senior High/Technical Schools in Eastern, Western and Central regions of Ghana.

The following research questions directed the study;

- What school-based health delivery administrative structures are available in senior high/technical schools in Eastern, Western and Central regions of Ghana?

- What are the conditions of school-based health centres/sickbays in senior high/technical schools in Eastern, Western and Central regions of Ghana?

- What school-based health practices have been put in place in senior high/ technical schools without school health centre/ sickbay in the Eastern, Western and Central regions of Ghana?

\section{Methodology}

Data was collected from public senior high/ technical schools in the Eastern, Western and Central regions of Ghana in order to describe the state of school-based health delivery. The data collected helped to describe the current status of health delivery in the schools. To this end, the descriptive cross-sectional census survey was adopted for the study. This design allows for the exploration of the current state of a phenomenon and its vivid description (Gall, Gall, \& Borg, 2007; Jackson, 2009; Neuman, 2014; Leavy, 2017). Creswell (2014) opines that the cross-sectional survey allows for the collection of data on a wide range or across board at the same time within a short period of time. This design allowed the researcher to collect data from all the senior high/ technical schools in the 3 regions identified for the study.

\subsection{Sample}

The population as well as the unit of analysis for the study was all public senior high/technical schools in the Eastern, Western and Central regions of Ghana. There are 210 public senior high/ technical schools in the Eastern, Western 
and Central regions of Ghana (Ministry of Education, 2017). In each of the schools a contact person (Teacher) accompanied the researcher during data collection.

Using the census method, all the public senior high schools in the three regions were selected for data collection. A census is a study of all units, individuals, entities, objects, etc in a population (Leavy, 2017). Therefore, the sample size for the study was 210 public senior high/ technical schools in the Easter, Central and Western regions of Ghana. Table 1 shows the distribution of schools per regions

\begin{tabular}{|c|c|c|c|}
\hline Region & Secondary & Technical & Total \\
\hline Central & 59 & 11 & 70 \\
Western & 46 & 4 & 50 \\
Eastern & 72 & 18 & 90 \\
\hline Total & 177 & 33 & 210 \\
\hline
\end{tabular}

Table 1: Distribution of Schools by Regions

\subsection{Instrument}

The instrument that was employed for this study was a structured observation guide. Observation as a method for data collection allows for the collection of live data from "naturally occurring social situations in siturather than relying on second-hand accounts" (Cohen, Manion, \& Morrison, 2007, p. 396). A structured observation guide is systematic and allows for the researcher to collect quantitative data through a passive non-intrusive role. The instrument was made up three main sections. Section A had indicators or items on availability of school-based health service administrative structures. Section B focused on the Conditions of Health facilities or Sick bays in the schools. And section C concentrated on Health delivery condition in school without health facilities. In all the structured observation checklist was made up of 20 items. The observation was to basically look at the availability or non-availability of some indicators of school-based health delivery in the schools selected. A pilot test was conducted in 40 public senior high/ technical schools in the Ashanti region to determine the reliability of the instrument. The reliability coefficient (Cronbach alpha) was determined to be .782 which was reliable.

\subsection{Data Collection and Analysis}

Permission was sought from the Headmasters of all the 210-senior high/technical schools. In each school, a teacher was nominated to accompany the researcher on the observation and data collection. The data collection exercise took seven weeks. Data collected from these schools were analysed using simple frequency counts and percentages. This was done with the help of Microsoft Excel (version 2018). Results were presented in Tables.

\section{Results and Discussions}

4.1. What School-Based Health Delivery Administrative Structures Are Available in Senior High/Technical Schools in Eastern, Western and Central Regions of Ghana?

This research question sought to find out the if there are any administrative structures put in place in the schools to aid school-based health delivery. Focus was on the availability of health delivery administrative structures, sickbays and the origins of the sickbays. Results from the observation indicated that, out of 210 senior high/ technical schools in the three regions, 152(72\%) had administrative structures for health delivery whiles 58(28\%) did not have. This means that the administration and leadership of these schools $(n=58,28 \%)$ have not even thought of or planned for health delivery services in their schools. This implies that, when a student gets ill in these schools, there is nothing the school can do to help. This defeats the purpose and role of school as espoused by Ofovwe and Ofilli (2007).

Results from Table 2 show that out of 210 senior high/technical schools involved in the study, 107 (51\%) had a Sickbay (School-based health delivery facility), whiles 103(49\%) did not have a Sickbay. In giving details based on the regional distribution, the central region had a higher percentage in terms of schools with sickbays.

\begin{tabular}{|c|c|c|c|c|c|c|}
\hline Region & \multicolumn{2}{|c|}{ Schools with Sickbay } & \multicolumn{2}{c|}{$\begin{array}{c}\text { Schools without } \\
\text { Sickbay }\end{array}$} & \multicolumn{2}{c|}{ Total } \\
\hline & No. & $\%$ & No. & $\%$ & No. & $\%$ \\
\hline Central & 37 & 53 & 33 & 47 & 70 & 100 \\
\hline Western & 25 & 50 & 25 & 50 & 50 & 100 \\
\hline Eastern & 45 & 50 & 45 & 50 & 90 & 100 \\
\hline Total & 107 & 51 & 103 & 49 & 210 & 100 \\
\hline
\end{tabular}

Table 2: Availability of Sickbays in Schools

In both the Western and Eastern regions half of their schools had sickbays whiles the other half did not. This gives vivid evidence of the failed collaboration expected between the Health and Education Ministries, confirming the study by Boateng (2008). Again, results from the observation showed that out of the 107 schools with sickbays, only 17 (16\%) were built as part of the original plan and architecture of the school. The rest (90) were either built by the Parents and Teachers Association (PTA) of the school or the Old Students Association. It will suffice to mention here that, it was revealed that 'Big' schools, and schools with vibrant old students' associations all had Sickbays. This implies that government and stakeholders of education in Ghana, do not factor school-based health service delivery when planning and executing the 
construction of the schools in the Eastern, Western and Central regions. This finding confirms the findings of studies (Ofovwe \& Ofilli, 2007; Toma, Oyebode, Toma, \& Agaba, 2014; Olugbenga, Olorunfemi, \& Opeyemi, 2016) conducted elsewhere that showed that there were no health centres or sickbays in almost all public schools.

4.2. What Are the Conditions of School-Based Health Centres/ Sickbays in Senior High/ Technical Schools in Eastern, Western And Central Regions of Ghana?

After establishing the administrative structures put in place in the senior high/technical schools in the regions, this research question sought to find out how schools with sickbays operate them. Focus was on the conditions of these sickbays. Results of the observation are presented in Table 3.

\begin{tabular}{|c|c|c|c|c|c|c|}
\hline Conditions & \multicolumn{2}{|c|}{ Available } & \multicolumn{2}{c|}{ Not available } & \multicolumn{2}{c|}{ Total } \\
\hline & No. & $\%$ & No. & $\%$ & No. & $\%$ \\
\hline Health professionals & 63 & 59 & 44 & 41 & 107 & 100 \\
\hline $\begin{array}{c}\text { Appropriate/ adequate } \\
\text { drugs }\end{array}$ & 75 & 70 & 32 & 30 & 107 & 100 \\
\hline Bed facilities & 60 & 56 & 47 & 44 & 107 & 100 \\
\hline Water facilities & 80 & 75 & 27 & 25 & 107 & 100 \\
\hline Proper ventilation & 74 & 69 & 33 & 31 & 107 & 100 \\
\hline Health prefects & 87 & 81 & 20 & 19 & 107 & 100 \\
\hline Transport facilities & 30 & 28 & 77 & 72 & 107 & 100 \\
\hline
\end{tabular}

Table 3: Conditions of Sickbays In Schools

Results from Table 3 show that out of 107 senior high/technical schools with sickbays, 63 (59\%) have qualified health professionals in-charge, whiles $44(41 \%)$ of them are managed by the School health prefect and the health team of the school. This means that out of the 210 schools studied, only 63(30\%) had health professionals, which is lower than what Toma, Oyebode, Toma, and Agaba, (2014) found in Nigerian schools. All the 63 schools had a nurse (mostly retired) at the sickbay. Out of the 63 schools managed by qualified health professionals, 33 had a Medical Doctor who visited the school every two weeks. It was discovered that $75(70 \%)$ of the schools had adequate and appropriate over the counter drugs and medical supplies whiles $32(30 \%)$ lacked basic drugs and medical supplies. Most of the sickbays also had bed facilities (56\%) and water facilities (80\%). The sickbays without bed facilities, had movable stretchers that students who report there sick are made to lay on. In sickbays without water facilities, big barrels filled with water were seen in the facilities. Most (87) of the schools had health prefects, whiles 20 did not have health prefects. In the schools without health prefects, the nurses where in-charge.Sadly, only 30 (28\%) out of 107 schools with sickbays had transport facilities to transport students to the Hospitals in case referrals becomes necessary. These findings corroborate findings of other studies (Keeton, Soleimanpour \& Brindis, 2012; Toma, Oyebode, Toma, \& Agaba, 2014; Olugbenga, Olorunfemi, \& Opeyemi, 2016; Bains, \& Diallo, 2016; Ran, Chattopadhyay, \& Hahn, 2016) on school-based health service delivery.

4.3. What School-Based Health Practices Have Been Put in Place in Senior High/Technical Schools Without School Health Centre/ Sickbay in The Eastern, Western and Central Regions of Ghana?

This research question sought to find out whether the senior high/ technical schools without sickbays have put in place any school-based health delivery services or practices in the schools. This was to find out how health care is delivered to students who may need it. Results from Table 4 show that Majority $(n=61,59 \%)$ of the schools without sickbays have appointed School Health Prefects and health teams to be in charge of health delivery. This goes to say that, 42 out of 103 schools without sickbays don't have any health delivery system in place. Implicitly, 42 schools out of the 210 schools in studied do not have either sickbays or health prefects; therefore, no school-based health delivery structures.

\begin{tabular}{|c|c|c|c|c|c|c|}
\hline Condition & \multicolumn{2}{|c|}{ Available } & \multicolumn{2}{c|}{ Not available } & \multicolumn{2}{c|}{ Total } \\
\hline & No & $\%$ & No. & $\%$ & No. & $\%$ \\
\hline Health prefect & 61 & 59 & 42 & 41 & 103 & 100 \\
\hline First Aid & 45 & 44 & 58 & 69 & 103 & 100 \\
\hline Transport facilities & 39 & 38 & 64 & 62 & 103 & 100 \\
\hline
\end{tabular}

Table 4: Condition of Schools without Sick Bays

Again, 58(69\%) out of the 103 schools without sickbays do not have First Aid facilities, only 45(44\%) did have First Aid facilities and handled by the Health prefect. So, in the 58 schools without sickbays and First Aid facilities, some students resort to chemicals shops (drugs stores) out of campus for medication when they fall ill whiles others use medicines they brought from home. Only 39 (38\%) of the schools without sickbays have transport facilities that can be used to transport students who fall sick to the hospital. In the $64(62 \%)$ schools without transport facilities, the benevolence of teachers who own vehicles are relied upon, whiles other resort to commercial vehicles to transport students who fall ill to the nearest hospital or clinic. Put together, almost half of the 103 schools without sickbays do not have Health prefects, First Aid and transport facilities. This means that in those schools, students' health is in their own hands. Students have to take charge of their health needs; school administration has nothing to do with it. In this vein, there is a contradiction of the assertion that schools have the most direct influence on a child's health (Ran, 
Chattopadhyay, \& Hahn, 2016). This finding confirms findings of other studies (Boateng, 2008; Keeton, Soleimanpour \& Brindis, 2012; Toma, Oyebode, Toma, \& Agaba, 2014; Olugbenga, Olorunfemi, \& Opeyemi, 2016; Bains, \& Diallo, 2016; Ran, Chattopadhyay, \& Hahn, 2016) on school-based health service delivery in other contexts.

\section{Conclusions and Recommendation}

Based on the findings from the results of the study, it becomes evident that almost half ( $n=103,49 \%)$ of the 210 public senior high/ technical schools in the Eastern, Western and Central regions of Ghana do not have school-based health delivery facility (Sickbay). This can be attributed to the fact that successive governments and stakeholders of education in Ghana have failed to factor school-based health delivery facilities when planning and executing the construction of schools. For the benevolence and hard work of PTAs and Old students' associations, only 17 (8\%) of the 210 schools would have Sickbays. Again, it can be concluded that, only 63 (30\%) of the 210 schools had a health professional, with only 33 (16\%) of these schools having a Medical Doctor visiting once every two weeks. Also, it can be concluded from the observation that, only 75 (36\%) of the 210 public senior high/ technical schools in the Eastern, Western and Central regions of Ghana have adequate and appropriate drugs in stock. Only 69 (33\%) out of the 210 schools have ample transportation facilities to support school-based health delivery whiles, $148(70 \%)$ out of the 210 schools had appointed school health prefects and health teams.

To remedy the state of school-based health delivery services in public senior high/technical schools in the Eastern, Western and Central regions, it is recommended that Government revisits the rationale behind School Health Education Programme (SHEP) to revive the need for health promotion and delivery and also reignite the supposed collaboration between the Ministry of Education and the Ministry of Health towards that direction. Government and stakeholders entrusted with the design, architecture and construction of public schools in Ghana should endeavour to make room for school-based health facilities (Sickbays). The Ministry of health should post at least one nurse (those on rotation, if not for permanent posting) and attach a Medical Doctor (who will visit the schools at least once a week) to public senior high/technical schools to help with the delivery of professional school-based health delivery. Ample transportation and appropriate/ adequate drugs should be made available to these schools to help school-based health delivery in the 210 public senior high/ technical schools in the Eastern, Western and Central regions of Ghana. To expand the frontiers of knowledge on the phenomenon of school-based health delivery in Ghana, a study of the other regions or a nationwide study should be conducted.

There is no doubt that this study attempted to fill the knowledge gap in the literature about the state of schoolbased health delivery in Public Senior high/technical schools in Ghana. Most of the studies conducted in Ghana did not focus on this context, however the findings of the present study did confirm as well as contradict the findings of previous studies conducted elsewhere. It will suffice to allude at this moment that, the conclusions drawn are based on the results, findings, sample and study area for the study.

\section{References}

i. Acosta Price,O. (2016). School-centered approaches to improve community health: lessons from school-based health centers.A Series of Discussion Papers on Building Healthy Neighborhoods, 5, 1-17.

ii. Bains, R.M., \& Diallo, A.F. (2016). Mental health services in school-based health centres: Systematic review. Journal of School Nursing, 32 (1) 8-19.

iii. Basch, CE. (2011). Healthier students are better learners: A missing link in school reforms to close the achievement gap. Journal of School Health, 81, 593-598.

iv. Boateng, N. A. A. (2008). Assessing the implementation and practice of the school health programme in some basic schools in the Kwabre district. Unpublished M.Sc. Health Services Planning and Management Thesis. Kwame Nkrumah University of Science and Technology

v. Cohen, L., Manion, L. \& Morrison, K. (2007). Research Methods in Education (6 $6^{\text {th }}$ ed.) New York: Routledge.

vi. Creswell, J. W. (2014). Research design: Qualitative, quantitative and mixed methods approaches. Los Angeles: Sage Publication

vii. Gall, M. D., Gall, J. P., \& Borg, W. R. (2007). Educational research: An introduction (8th ed.). Toronto: Pearson Education, Inc

viii. Geierstanger, S. P., Amaral, G., Mansour, M., \& Walters, S. R. (2005). School-Based health centres and academic performance: Research, challenges, and recommendations. Journal of School Health, 74(9), 347-52.

ix. Gustafson, D. L. (2005). Transcultural nursing theory from a critical cultural perspective. Advanced Nursing Science, 28 (1), 2-16.

x. Jackson, S. L. (2009). Research methods and statistics: A critical thinking approach (3 $3^{\text {rd }}$ ed.). Belmont: Wadsworth.

xi. Keeton, V., Soleimanpour, S. \& Brindis, C. D. (2012). School-Based Health Centres in an Era of Health CareReform: Building on History. Current Problems in Paediatric and Adolescent Health Care, 42, 132-156

xii. Leavy, P. (2017). Research design: Quantitative, qualitative, mixed methods, arts-based and community-based participatory research approaches. New York: The Guilford Press.

xiii. Neuman, W. L. (2014). Social research methods: Qualitative and quantitative approaches (7th ed.). Essex, UK: Pearson Education Ltd.

xiv. Nyonator, F. K., Awoonor-Williams, J. K., Phillips, J. F., Jones, A. C., \& Miller, R. A. (2005). The Ghana Communitybased Health Planning and Services Initiative for scaling up service delivery innovation. Health Policy and Planning, 20, (1), 25-34 
xv. Ofovwe, G., E., \&Ofili, A., N. (2007). Knowledge, attitude and practice of school health programme among head teachers of primary schools in Egor local government area of Edo state, Nigeria. Annals of African Medicine 6, (3), 99-103

xvi. Olugbenga, T. K., Olorunfemi E. A.\& Opeyemi T. K. (2016). School health services and its practice among public and private primary schools in Western Nigeria. BMC Res Notes, 9: 203.

xvii. Proctor, S.T., Lordi, S.L., \& Zarger, D.S. (1993). School Nursing Practice Roles and Standards. Scarborough, Maine: National Association for School Nurses.

xviii. Ran, T., Chattopadhyay, S. K., \& Hahn R. A. (2016). Economic Evaluation of School-Based Health Centres a Community Guide Systematic Review. American Journal of Preventive Medicine, 51(1), 129-138

xix. Small, M. L., Majer, L. S., Allensworth, D. D., Farquhar, B. K., Kann, L., \& Pateman, B. C. (1995). School Health Services. Journal of School Health, 65 (8), 319-326.

xx. Strolin-Goltzman, J. (2010). The relationship between school-based health centres and the learning environment. Journal of School Health, 80, 153-159.

xxi. Tierozie, C. (2011). Impact assessment of the community-based health planning and services initiative in the Berekum municipality. Unpublished Executive Masters in Public Administration Thesis. Kwame Nkrumah University of Science and Technology

xxii. Toma, B. O., Oyebode, T., Toma, G. I.O., \& Agaba, E. (2014). School Health Services in Primary Schools in Jos, Nigeria. Open Science Journal of Clinical Medicine, 2, (3), 83-88.

xxiii. Vessey, J. A., \& McGowan, K. A. (2006). A successful public health experiment: School nursing.Pediatric Nursing, $32,(3), 255-256$.

xxiv. Weinstein, J. (2006). School-based health centers and the primary care physician: An opportunity for collaborative care. Primary Care: Clinics and Office Practice, 33, 305-31 